\title{
Superior Class Management during Covid-19 at MTs Islamiyah Barbaran Academic Year 2020/2021
}

\author{
Candra Wijaya', Faisal Musa², Muhammad Arifin Ritonga ${ }^{3}$, Munzir $^{4}$, Nurdin $^{5}$ \\ ${ }^{1}$ Universitas Islam Negeri Sumatera Utara, Indonesia \\ 2,3,4,5 Doctoral Program, Universitas Islam Negeri Sumatera Utara, Indonesia
}

\section{Abstract}

The Covid-19 pandemic has had a wide impact on various aspects of human life, especially education, so it needs to be reorganized or managed again, in accordance with the demands of implementing learning during Covid-19. The aim is that madrasahs still have an advantage over schools in general. MTs Islamiyah Barbaran is one of the madrasas in Mandailing Natal Regency which for approximately 8 years has implemented a superior class system learning pattern, to accommodate the demands or needs of smart or superior students. The ability of MTs Islamiyah Barbaran in managing superior classes so as to produce sufficient quality output or graduates makes this madrasah always in demand, and gets a good response from the community. In this regard, this study will examine the implementation of superior class management during covid-19 at MTs Islamiyah Barbaran, using a qualitative approach, the methods used in this study are the methods of interviewing, observation and documentation. The data analysis method uses qualitative descriptive analysis which consists of four stages, namely data collection, data reduction, data display and conclusion or verification. Withdrawing conclusions using the inductive method. The results of this study indicate that the principal of the madrasah has carried out superior class learning innovation management during the Covid19 pandemic at Islamic Private MTs Barbaran TP. 2020/2021, namely by implementing several policies, such as online learning, flexibility of lesson hours, IT development, and maintaining daily protocols, by implementing management functions, namely planning, organizing, actuating, and controlling. In addition, committee empowerment is one of the main keys to the success of these MTs in managing superior classes.
Keywords

madrasah; management;

featured classes

\section{Introduction}

It is sunnatullah that humans have different talents and abilities. There are students who have ordinary abilities, but not a few of them have bright abilities and talents or are very intelligent, unlike children in general. Among them, gifted children are characterized by their ability to think that is flexible, critical, has bright ideas, broad knowledge and a strong curiosity compared to children in general.

Recognition of the special needs of gifted children is accommodated in Law Number 20 of 2003 concerning the National Education System, as well as being the basis for implementing superior class programs or accelerated classes. Gifted children or children who have educational needs that are not like children in general, because their intelligence 
has the right to get proper education according to their needs, one of which is done by opening a system or superior class program, or previously known with the acceleration program.

The existence of a superior class is an acknowledgment of the diversification or diversity of potential that each student has. Every student has the right to receive education or teaching according to his / her talent and level of intelligence. In chapter 5, article 4 of Law Number 20 of 2003 explicitly states that: "citizens who have the potential for intelligence and special talents are entitled to special education."Furthermore, in Chapter V article 12 Paragraph 1 point "b" emphasizes that, "Every student in each education unit has the right to receive educational services according to their talents, interests and abilities.

Thus, it is clear that the superior class is one of the places or institutions that are prepared to facilitate gifted students, so that they can develop their talents and potential to the maximum. Featured students are dissected based on certain conditions or criteria, namely based on the measurement results of intelligence (potential IQ), and academic talents possessed by prospective students which are generally carried out at the time of admission of new students in each new academic year.

MTs Islamiyah Barbaran is a private madrasa that has implemented superior classbased learning or superior class programs. MTs Islamiyah Barbaran which was founded in 2010 and is located in Barbaran Village, Kec. Panyabungan Barat Kab. Mandailing Natal Prov. North Sumatra is one of the most outstanding madrassas, compared to similar MTs in Mandailing Natal Regency. The researchers' observations show that public interest in this madrasah is increasing day by day. From only 32 students in 2010, by 2020 the students had reached 380 students, or with an average of 120 new registrants each year.

The phenomenon is that madrassas are often underestimated, namely only as places to produce religious scientists (ulama), while in the field of science and technology madrasas are considered failures or at least less capable of producing reliable alumni, madrasas are even labeled as educational institutions conditions with problems, and a number of unfavorable labels, it seems that this is not the case at MTs Islamiyah Barbaran.

In fact, there is something unique about MTs Islamiyah Barbaran at this time, namely the growing interest in this institution as a destination or choice of secondary school for MTs level in Mandailing Natal Regency, especially in Kec. Panyabungan West. In fact, in this area there are several junior high schools (SMP and MTs as well as Islamic boarding schools) which actually can also be their choice of study.

However, in 2019, on December 31, 2019 to date (2021), a case of unknown pneumonia emerged in Wuhan, China which was caused by the corona virus or known as COVID-19 (Corona Virus Deseses-2019) with the speed of spreading. COVID-19 has a very large impact on the atmosphere of tourism globally, especially in 2020 . With a very fast spread, COVID-19 can make various countries in the world self-quarantine and affect 60 million people around the world both economically, socially, and environmentally (Zandi in Sinulingga, 2021). Which is very high, and until now it has become a global phenomenon in almost all countries in the world. One of the impacts of the Covid-19 phenomenon is that all people or residents without exception have to carry out social distancing or physical distancing or what is called large-scale social distancing. One of the conditions like this has an impact on education, which cannot be done offline or face-toface as usual.

Education is very important to human beings especially to youngsters because this serves as their stepping-board in achieving their goals in life. It is so hard to imagine if education stops. At present, all countries in the world are facing a national health emergency because of the Covid-19 (Corona Virus) pandemic which was originated in the 
province of Wuhan in China. This disease causes a lot of circumstances such as lung infections, flu, fever, and sometimes death. The World Health Organization reiterated that "the COVID-19 is an infectious disease caused by a newly discovered coronavirus. (Reotutar, 2020). Changes in the new life order, especially during Covid-19, require the world of education, including madrassas to respond quickly to this situation, ensuring that children's education can continue even though it cannot be maximized as usual, so that the nation's children, especially those in madrasas can still learn even in the Covid-19 pandemic conditions.

Based on this background, the researchers are interested in conducting research on management strategies for superior class management, which is one of the characteristics and at the same time the superior program at MTs Islamiyah Barbaran, so as to be able to bring this school into a school of interest, especially in the Mandailing Natal Regency area. with the title "Superior Class Management at MTs Islamiyah Barbaran During Covid-19 TP. 2020/2021".

\section{Review of Literature}

\subsection{Madrasah and the Urgency of Excellent Class}

Historically, madrasas have grown and developed for quite a long time, even becoming one of the most influential Islamic educational institutions in the archipelago. Since the beginning of its existence, madrasas have played a major role in producing a number of figures and scientists who were very instrumental in the struggle process and in filling the independence of the Republic of Indonesia. Although it cannot be denied, that since independence until the early 21 st century the role of madrasas has not been paid attention by the government of the Republic of Indonesia, even discriminatory, as if forgetting history, that madrasas were at the forefront of every struggle to seize and defend the Unitary State of the Republic of Indonesia (NKRI) from colonial hands.

The influence of madrassas was getting dimmer, especially with the increasing influence of Western-style general education introduced by the Dutch at that time, the work and existence of madrasas became less attention and even tended to receive less fair treatment from the government. In society, madrasas are often underestimated, only as a place to produce scientists in the field of religion (ulama), while in the field of science and technology madrasas are considered failures or at least not capable of producing reliable alumni.

The twentieth century is a century of madrasa revival after a long period of not getting a proper place in its own country. Even in deadly areas the development of madrassas is increasingly significant from year to year. With the enactment of Law Number 2 of 1989 concerning the National education system and Law Number 20 of 2003, madrasah educational institutions have been placed in their rightful position, namely as one of the National education sub-systems that deserve to be considered and preserved. Many madrasas have been established by the community and financed personally by the community, so since the enactment of the National Education System Law Number 20 of 2003, madrasah education is not only the responsibility of the community but also the responsibility of the government, both in terms of funding, development, and in terms of quality and quality improvement. .

To restore public confidence in madrassas and to increase their role and work in educating and supporting national development, madrasas from an early age need to make reforms or at least need to make new innovations while maintaining their identity as schools characterized by Islam. One of them is by innovating superior class programs (a 
kind of accelerated program) in madrasas which are prepared for superior children or gifted children. Excellent class program management is very important. With this management will make it easier to achieve learning objectives and minimize errors. In the hadith of the Prophet it is stated that Allah likes people who when they do an action they do it perfectly, which reads:

Meaning: "Surely Allah is happy if someone among you does an act then he does it perfectly"8. (Reported by Al-Ṭabrānī)

The hadith indirectly emphasizes the importance of order in everything, including in this case the superior class program. With good management, efforts to achieve goals will be effective and efficient. There are several reasons, or the basis for the importance of making superior classes at the madrasah level such as MTs. Among others are:

a. Changes in the world that are increasingly advanced;

b. The complexity of people's lives;

c. Increasingly diverse job demands;

d. Development of science and technology; and

e. The importance of preparing for a better future.

Meanwhile, the objectives of holding excellent classes at madrassas include:

1. Meet the needs of students who have specific characteristics in terms of cognitive and affective development.

2. Fulfill the basic rights of students

3. Fulfill the intellectual interest and future perspectives of students

4. Fulfill self-actualization

5. Prepare students as leaders who are able to make quick decisions.

6. Provide rewards for being able to complete education programs faster.

7. Improve the efficiency and effectiveness of the learning process

8. Prevent boredom of the classroom climate that is less conducive

9. Increase spiritual, intellectual and emotional intelligence in a balanced manner.

Gifted or intelligent children are valuable assets owned by a country. They will be able to make a meaningful contribution to the progress of society and the state, especially if their rights in education are best served or fulfilled, because the more effective and more effective the education of a child is, the more it will contribute to the progress of a nation. So in order to protect their rights and to motivate these gifted and superior children in education, it is necessary to have a special treatment in their education, one of which is done through an acceleration program or what is called a superior class.

The positive impacts obtained from implementing superior classes include increased academic achievement of superior class students compared to their peers in regular classes, increased student motivation, and increased parental participation in education. However, there are also negative impacts, including the emergence of an exclusive attitude or feeling wider than regular class students. Often times, top class students distance themselves from their peers in the regular class, and at the same time regular class students also keep their distance from their friends in the superior class, but in general, the superior class has a positive impact on the development of the madrasah. 


\subsection{The Covid-19 Pandemic}

Starting from the beginning of the end of 2019 or early 2020, the entire world community was shocked by the outbreak of the Corona virus (COVID-19) which has spread in almost all countries in the world. The World Health Organization (WHO) since January 2020 has stated the situation world that has entered into a state of global emergency due to the spread of this virus. The corona virus is a type of virus that attacks the human respiratory system and it is recorded that more than 111 million people have been infected with this virus in 213 countries around the world. Quoted by PikiranRakyat.com from the Worldo Meters page, as of Sunday, February 21, 202, the exact total has reached 1,278,653positive cases of COVID-19. The global epidemic that has hit the world, and Indonesia in particular, is thus still the main problem of our nation, so that government programs regarding online learning suggestions (learning online) and stay at home must continue to be implemented as an effort to suppress the spread of Covid19.

For this reason, the learning model is also transferred to online classes or virtual learning, so that all students still have their right to gain knowledge but are still safe at home. Buana (2020) explains the steps that have been taken by the government to be able to solve this extraordinary case, one of which is by socializing the social distancing movement. This concept explains that in order to reduce or even break the chain of Covid19 infection, one must maintain a safe distance from other humans of at least 2 meters, and not make direct contact with other people, avoiding mass gatherings.

\subsection{Excellent Class Management}

Basically, management is not something new in human life. Although scientifically, management was only formulated around the early 19th century, but the practice has been going on for thousands of years. The word management comes from the word manus which means hand and agere which means to do. The words are then combined to become manager which means to handle. The term management actually refers to the process of carrying out activities that are completed efficiently with and through the empowerment of others. This is in line with what GR Terry said as quoted by Yayat M. Herujito, that management is a process which consists of planning, organizing, actuating, and controlling.

Rahmat Hidayat, et al explained that management is an activity carried out together through a person or group with the intention of achieving goals, common goals of the organization. 4 Thus, management is a series of activities which include planning, organizing, mobilizing and controlling carried out to achieve goals. which has been determined through the use of human resources and other resources. 5

Thus, superior program management can be interpreted as an effort to mobilize all resources owned by madrasahs through collaboration between various stakeholders in managing superior class programs optimally, by applying management principles to support the achievement of the expected educational goals.

The scope of superior class education management includes all things or activities that support the achievement of superior class goals. The scope of superior class management in general is the scope of education management in general, both schools and madrasahs, namely: curriculum management, Management of students, Management of Human Resources / Personnel, Financial Management, Management of infrastructure, Public relations management. 


\subsection{Implementation Preparation Strategy}

In the context of implementing superior class programs, various kinds of preparations need to be made, including the following:

1. Hold consultations and intensive communication with schools or madrasahs that have previously implemented the program, to obtain various information and inputs;

2. Forming a small team of accelerated programs in the organizing madrasah consisting of madrasah principals, madrasa deputy principals, and teachers who have the care, expertise and attention to provide services for students who have special intelligence and / or talents.

3. Providing provision and insight into the accelerated program by inviting resource persons or madrasah / school managers that have implemented the program, which is attended by all stakeholders in the madrasah / school who will be involved in implementing the accelerated program;

4. Selecting teachers who will teach in the program to ensure the quality of teacher competence;

5. Arrange a work program for implementing an accelerated program in madrasah as outlined in the madrasah work plan.

\section{Research Methods}

\subsection{Types and Research Approaches}

This research is a field research (field research), using a qualitative descriptive approach, namely research procedures that produce descriptive data in the form of written or spoken words from people and observable behavior. This type of research is intended to obtain information about superior class learning management at MTs Islamiyah Barbaran in the 2020/2021 school year.

\subsection{Place and Determination of Research Subjects}

The place used in the research is MTs Islamiyah Barbaran in Barbaran Village, West Panyabungan District, Mandailing Natal Regency. Meanwhile, the subjects of this study are teachers who teach excellent classes, deputy head of the curriculum section, and head of madrasah.

\subsection{Method of Collecting Data}

To obtain data from research sources, there are several data collection methods used.

The collection methods in this study are:

1. Interview Method (Interview)

Interview (Interview) is a way of obtaining data face to face, having a conversation, both between individuals and individuals and individuals with groups. In this research, an interview is needed to determine the superior class learning management at MTs Islamiyah Barbaran. Interviews were conducted with teachers who teach in superior classes, principals and vice principals of the curriculum section.

2. Observation Method

Observation is defined as observing and recording systematically the symptoms that appear on the object of research. The observation method is used to determine the learning process that takes place in the superior class at MTs Islamiyah Barbaran.

3. Documentation Method

Documentation is a research method aimed at obtaining direct data from the research site including relevant books, regulations, activity reports, photographs, documentary 
films, and relevant research data. Documentation is used to obtain the necessary data, such as the history of the establishment of MTs Islamiyah Barbaran, the vision and mission, the teacher's condition, and the student's condition.

\subsection{Data Analysis Method}

In analyzing the data, the researcher used the Miles and Huberman model with a qualitative descriptive analysis process, which consisted of four stages, namely data collection, data reduction, data display and conclusion or verification. Data collection was carried out through observation, interviews, and documentation. After the data was collected, a reduction was carried out which was intended as a simplification so that it was easier to analyze. Then the results of the reduction are organized and presented. And the last stage is drawing conclusions using the inductive method. The inductive method is a reasoning process in which observations or observations form the basis for formulating theories, hypotheses and interpretations.

\section{Results and Discussion}

Based on the theory presented in the theoretical basis, and the data found in the field, data analysis will be carried out here on superior class learning management at MTs Islamiyah Barbaran. The things that will be analyzed are learning planning, organizing learning, implementing learning, and implementing strategies for superior classes for the 2020/2021 school year, as follows:

\subsection{Curriculum Management}

Management of the curriculum for superior madrasah or superior classes in the pandemic era is different from the curriculum standards before the pandemic, which previously focused on offline or offline learning. So during the pandemic, according to the direction of the Ministry of National Education and the Ministry of Religion, the learning system must be adapted according to the demands of the situation. The curriculum must be designed as flexible and as easy as possible and of course adapted to developments in information technology 4.0.

In this case, the head of MTs Islamiyah Barbaran together with superior class academic advisors and educators sit together, synergize and formulate an appropriate and adaptive curriculum format during the Covid-19 pandemic, with reference to the signs issued by the Ministry of National Education. The learning material during Covid-19 is delivered using the assignment method, namely by giving homework to students, but after students get an explanation from the teacher online. For superior classes, the manager sets 4 additional subjects each week, from Monday to Friday and is given after 14:15 every day.

\subsection{Management of Students}

Student management is carried out by setting a quota for superior class students, which is only 25 people each year, then setting a schedule for new student admissions, and then selecting new prospective students for superior classes through written and oral tests which are carried out offline at madrasah but by implementing health protocols. After obtaining the test results, students are divided into classes, then set a learning schedule, especially for additional subjects as many as 4 subjects with a weight of 8 lesson hours / week. All students who are declared accepted are required to comply with the rules and regulations specified for superior class students, including to take part in specified additional learning activities. 


\subsection{HR / Personnel Management}

Competent and quality human resources (HR) are the main prerequisites for the implementation of education services in madrassas, especially during the Covid-19 pandemic. Strong and competent human resources will ensure the implementation of ITbased education services and will ensure the delivery of learning materials to students effectively and efficiently. Therefore, after selecting the superior class teacher candidates, and after determining the person in charge for implementing the superior class, the picket officer, then the skills and skills of the teaching staff at MTs Islamiyah Barbaran are improved through training, webinars, discussionson line, which is focused on developing insight and communication skills and learning techniques using media on line, making online questions using the google form application.

Continuous education and training for all educators and education personnel need to be done so that their skills and knowledge are continuously updated, so that educational services or teaching to students are still carried out well. Along with the era of technology 4.0, human resources who are ready to continue to change and adapt to technological developments will greatly determine the success of an educational institution.

\subsection{Financial Management}

As with other management elements, finance also occupies an important thing in every organization. Without good financial or financial support, it is impossible for an organization to function properly. In managing superior class finance, it is necessary to plan, utilize funds, and report financial or financial accountability. Effectiveness and accountability, as well as efficiency in financial management are important principles and must also be considered in financial management.

Especially during covid-19, premium class financing is not collected because it is subsidized from BOS funds. The madrasah also provides additional internet quota to all educators who teach in superior classes. At the time before the pandemic, the cost of implementing the superior class was Rp. 45,000 after obtaining approval from the committee and parents of students.

\subsection{Infrastructure Management}

Facilities and facilities from the perspective of education management are also very important, because they will support the learning process. The infrastructure in the Covid19 pandemic must of course also comply with the standard Covid-19 preventive health protocol. This concerns the security and safety of students and teachers during the teaching and learning process or in the context of face-to-face activities at schools or madrasas. The supporting facilities prepared by MTs Islamiyah Barbaran are a school environment that is facilitated with standard hygiene tools for prevention of Covid-19, such as masks, faceleads, water, soap, handsanitizer, a tool to check students' body temperature.

The classrooms are arranged in such a way that the distance between students from one another is at least 1 meter or if possible, two meters. And this certainly affects the number of students in the room, especially the use of classrooms which is only half of all existing capacities. Next is the schedule arrangement or by going in turn (shift).

In addition, the school directs all students to use the zoom and WhatsApp applications to support online teaching and learning activities outside of school. In addition, Google Classroom, an online education portal such as a teacher room, is also used for teaching and learning activities. But in general, you still use the zoom and whatsapp applications. 


\subsection{Public Relations Management}

The Covid-19 pandemic demands active communication between madrasa education managers and the community or parents. This is because there is a lot of information about regulations or regulations regarding the implementation of learning during the pandemic that may not be understood by parents. In addition, the implementation of learning outside of school that does not usually require the activeness and participation of parents in guiding and supervising the implementation of online student learning at home.

Information related to demands for learning and learning systems during the Covid pandemic is periodically conveyed to parents, through WhatsApp media, and online letters issued by madrassas. In other words, communication between parents and madrasah is maintained through WhatsApp and other media. Apart from parents and students, the superior class management also communicates with several high schools which will later become secondary schools for alumni of MTs Islamiyah Barbaran. The school continues to provide information to students and parents about secondary schools that may be students' choice.

Based on the analysis of the research findings above, it can be concluded that the planning carried out by MTs Islamiyah Barbaran during Covid-19 is no longer collaborating with a second party, namely a psychologist who in previous years was used as an indicator for determining superior or gifted students. However, madrasah still conducts selection by gathering students at school and conducting a series of tests or exams with 4 main subjects, including mathematics, science, language, and interviews with students and parents of students, carried out by following standard health protocols. Thus, there is a correspondence between the theory used by the researcher and the research results presented in the research findings.

Learning outside the madrasa is done online or online using the WhatsApp application and zoom, and sometimes also by using the google classroom application.

\subsection{Learning Assessment at MTs Islamiyah Barbaran}

Assessment of student learning is carried out by providing periodic evaluations to students, both daily evaluations, mid-semester and at the end of the semester. From test scores, assignments, semester scores and also test scores, as well as applications in everyday life, students are assessed whose results are written in a report card or list of student achievement scores submitted at the end of each semester. Which of the results of these scores will be reported to the parents of each child in the form of sheets of children's learning reports while at MTs Islamiyah Barbaran.

Based on the above analysis, it can be concluded that the supervision of superior class learning at MTs Islamiyah Barbaran is good, as evidenced by the existence of a report sheet on children's learning outcomes that will be reported to the parents of each child and there is an agreement between the theory that the researcher previously described on the theoretical basis with the data that is found. 


\section{Conclusion}

Based on the exposure and analysis of the research findings, it can be concluded that the superior class learning management at MTs Islamiyah Barbaran during the Covid-19 pandemic in the 2020/2021 school year, is as follows:

1. Learning planning at MTs Islamiyah Barbaran includes: recruitment of superior class students with a selection test in the new academic year containing religious knowledge and general knowledge, determining subject components for superior classes, namely the existence of additional subjects in Mathematics, Science, Language and taḥiz , there is coaching and self-development of students through extracurricular activities but it doesn't work well because of the covid-19 pandemic.

2. Organizing learning at MTs Islamiyah Barbaran includes: preparation of lesson schedules, preparation of extracurricular activity schedules, formation of school organizational structures, and the division of tasks for teachers and employees, adjusted to the demands of learning in the Covid-2019 era.

3. Implementation of learning at MTs Islamiyah Barbaran, namely the addition of additional subjects in the superior class which is carried out 5 days a week which contains 8 hours of face-to-face, each of which contains 2 hours of face-to-face and everything is done online.

4. Learning assessment at MTs Islamiyah Barbaran through daily test activities, assignments, semester tests, test scores and also the application of actions in everyday life. From the results of student learning reported to their parents in the form of sheets of children's learning outcomes during school at MTs Islamiyah Barbaran, carried out offline and online.

\section{Suggestion}

Without reducing respect for all parties, researchers try to provide input on the management of superior classroom learning, including:

a. The head of madrasah should improve the skills of teachers and students in using webbased learning applications, especially in making questions online via google classroom or google form to support the government's demands for the online learning system during covid-19.

b. Madrasahs are able to improve computer facilities and infrastructure to support the implementation of superior classes for the better,

c. The principal can increase the honorarium or transport of superior class teachers, to motivate teachers to carry out their duties as coaches and teachers in superior classes.

\section{References}

Departemen Agama Republik Indonesia. (2007). Al-Qur'an dan Terjemahnya (Bandung: Madina Raihan Makmur)

Herdiansyah, Haris. (2010). Metodologi Penelitian Kualitatif (Jakarta:Salemba Humanika)

Hambali, Muh. et al. (2020). Manajemen Pendidikan Islam Kontemporer (Yogyakarta: IRCiSoD)

Majid, Abdul. (2012). Belajar dan Pembelajaran (Bandung: Remaja Rosdakarya)

Margono. (2010). Metodologi Penelitian Pendidikan (Jakarta: Rineka Cipta)

Moeloeng, Lexy. (2007). Metode Penelitian Kualitatif (Bandung:Remaja Rosdakarya)

Muhaimin. (2010). Manajemen Pendidikan (Jakarta: Kencana) 
Kutha Ratna, Nyoman. (2010). Metode Penelitian Kajian Budaya dan Ilmu-Ilmu Sosial dan Humoniora Pada Umumnya (Yogyakarta: Pustaka Pelajar)

Rahmad, Hidayat. et.al. (2020). Ayat-Ayat al-Qur'an Tentang Manajemen Pendidikan (Medan: LPPI)

Reotutar, Mark Angelo C. (2020). Teacher Education Freshmen Applicants' Current State in the New Normal's Learning Delivery Platforms. Budapest International Research and Critics in Linguistics and Education (BirLE) Journal. P. 1528-1536.

Riduwan. (2010). Belajar Mudah Penelitian Untuk Guru, Karyawan dan Peneliti Pemula (Bandung: Alfabeta)

Rosyada, Dede. (2017). Madrasah dan Profesionalisme Guru dalam Arus Dinamika Pendidikan Islam di Era Otonomi Daerah (Depok: Kencana)

Sinulingga, S. (2021). Tourism \& Covid-19 (Coronavirus Impact Inventory to Tourism Stakeholders in North Sumatera). Budapest International Research and Critics Institute-Journal (BIRCI-Journal). P. 170-179.

Undang-Undang Republik Indonesia No 20 Tahun 2003, http://www.kemenag.go.id, diakses 12 Januari 2021 pada pukul 12.08.

Yayat, M. Herujito. (2001). Dasar-Dasar Manajemen (Jakarta: Grasindo) 